\title{
Graft Compatibility and Anatomical Studies of Bitter Gourd (Momordica charantia L.) Scions with Cucurbitaceous Rootstocks
}

\author{
N.A. Tamilselvi ${ }^{1}$ and L. Pugalendhi ${ }^{2}$ \\ ${ }^{1}$ Department of Vegetable Crops, Horticulture College and Research Institute, \\ Tamil Nadu Agricultural University, Coimbatore-641 003, India \\ ${ }^{2}$ Tapioca and Castor Research Station, Yethapur, Salem-636 119, India \\ *Corresponding author
}

\begin{tabular}{|l|}
\hline K e y w o r d s \\
$\begin{array}{l}\text { Compatibility, } \\
\text { Graft union, } \\
\text { Survival rate, Bitter } \\
\text { gourd, Rootstocks, } \\
\text { Graft anatomy. }\end{array}$ \\
\hline Article Info \\
\hline $\begin{array}{l}\text { Accepted: } \\
\text { 24 January } 2017 \\
\text { Available Online: } \\
\text { 10 February } 2017\end{array}$
\end{tabular}

\section{A B S T R A C T}

A study was carried out to determine the graft compatibility of bitter gourd scions (Palee $\mathrm{F}_{1}$ and $\mathrm{CO} 1$ ) with ten different cucurbitaceous rootstocks. The grafting technique adopted in this study was side grafting. Graft compatibility was determined by assessing the survival rate of the grafted plants after regeneration of vascular bundles across the graft interface and vegetative growth of the scion. The results on grafting success at 45 days after grating (DAG) revealed that the highest survival percentage $(71.70 \%)$ was observed in Palee $\mathrm{F}_{1}$ scion grafted onto pumpkin (Cucurbita moschata) rootstock followed by Palee $\mathrm{F}_{1}$ scion grafted onto sponge gourd (Luffa cylindrica) rootstock $(68.26 \%)$ and lowest success per cent $(12.12 \%)$ was obtained in mithipakal (Momordica charantia var. muricata) (Cucurbita ficifolia) rootstock with CO 1 scion. In order to study the ultra structural changes and compatibility of bitter gourd scions, the anatomical study were conducted in two graft combinations viz., Palee $\mathrm{F}_{1}$ grafted onto pumpkin (C. moschata) rootstock and fig leaf gourd (C. ficifolia) rootstock at four different stages viz., $7^{\text {th }}, 15^{\text {th }}, 21^{\text {st }}$ and $30^{\text {th }}$ days after grafting. Vascular regeneration across the graft interface was seen in Palee $F_{1}$ scion grafted onto pumpkin (C. moschata) rootstock. Graft incompatibility was observed in $\mathrm{CO}$ 1 bitter gourd scion grafted onto fig leaf gourd (C. ficifolia) rootstock could be attributed to the presence of a necrotic layer at the graft interface. This suggests that pumpkin $(C$. moschata) rootstock could be the compatible rootstock for grafting with bitter gourd scions.

\section{Introduction}

Bitter gourd (Momordica charantia) is economically important vegetable crop grown in Southeast Asia. The crop is cultivated over an area of 80,990 ha in India with an annual production of $8,30,450$ tonnes and the productivity of 10.25 $\mathrm{th}^{-1}$ (Anon, 2015-16). The rigorous cultivation of bitter gourd has favoured the increase of plant health problems. Among these problems, the rootknot nematode (Meloidogyne incognita) and Fusarium wilt (Fusarium oxysporum f. sp. momordicae) stands out (Tamilselvi, 2014). The root knot nematode is one of the important pests of bitter gourd and reported to cause 38 to $48.2 \%$ yield losses (Kaur and Pathak, 2011). Among the root knot nematode species Meloidogyne incognita is major pest causes significant loss in quality and quantity of production and showed high pathogenic potential on bitter gourd (Singh et al., 2012; Gautam and Poddar, 2014). The suspension of continuous use of agrochemicals due to its 
environment-unfriendliness results in shifting towards alternative strategy that included the use of resistant rootstocks.

Compatibility of the scion and rootstock is a biological expression. The success of grafting depends on the union of the grafts (rootstock and scion) and compatibility of the rootstock and scion. In order to improve grafting success, early prediction of graft compatibility is very essential (Elazar and Zoran, 2014). A successful graft union starts with a series of events such as multiplication of the callus from the scion and rootstock, formation of a callus bridge, vascular separation and production of the xylem and phloem (Hartman and Kester, 2011). Critical factors such as compatibility of the rootstock and scion, direct contact of the vascular cambium of the rootstock and scion, proper functional state of the rootstock and scion, prevention of withering, proper care of the grafted plants as well as skill of the grafter are required to warrant the success of the graft union (Kleinheinz et al., 2013). Additionally, fundamental environmental elements such as temperature and relative humidity must be met to guarantee the successful graft union. These are critical factors that greatly affect the success of a graft union (Alai, 2014). Relative humidity also affects callus formation in various ways. Too much or low relative humidity creates conditions necessary for the development of disease and wilts. For that reason, it is important that conducive environment with optimum relative humidity and temperature to enhance the healing of the graft union are provided (Kleinheinz et al., 2013). Hence proper selection of rootstock/scion combinations can help to controls the soil borne diseases, increases yield and improve the fruit quality along with long shelf life (Nkansah et al., 2013).

Unproductive graft union can be caused by mismatching of the scion and rootstock, lack of skill and expertise, adverse environmental conditions, diseases and incompatibility (Hartman and Kester, 2011). The most obvious is rootstock/scion incompatibility, which induces undergrowth and/or overgrowth of the scion, leading to decreased water and nutrient flow through the graft union, ultimately causing wilting (Davis et al., 2008). The difference in enzyme activity between the rootstock and the graft joining region during the healing process influences the performance of grafted plants and could be used as a rapid mechanism to verify incompatibility (Kohatsu et al., 2013). Characterization of incompatibility is not a simple process because graft combinations can unite initially with apparent success, but gradually develop incompatibility symptoms with time, due to either failure at the union or the development of abnormal growth patterns. Hence, an early and accurate prediction of graft incompatibility has great importance because incompatible combinations could be avoided while compatible once can be selected.

Despite the widespread use of grafting, information about scion and rootstock compatibility is still lacking. Hence, this study was conducted to assess the graft compatibility of bitter gourd scions with cucurbitaceous rootstocks based on the success percentage of graft combinations and microtome study.

\section{Materials and Methods}

\section{Experimental site and plant materials}

The research was carried out from 2013 to 2014 in the experimental farm of the Department of Vegetable Crops, Tamil Nadu Agricultural University, Coimbatore, India $\left(11^{0} \mathrm{~N}\right.$ latitude, $77^{0} \mathrm{E}$ longitudes and an altitude of $426.26 \mathrm{~m}$ above mean sea level). The hybrid, Palee $F_{1}$ from East West Seed Company, Philippines which is popularly 
cultivated $F_{1}$ hybrid in Tamil Nadu and the other one is CO 1, a cultivar from TNAU that were used as scions and the rootstocks viz., number of days taken for germination Mithipakal (Momordica charantia var. muricata), fig leaf gourd (Cucurbita ficifolia), pumpkin (Cucurbita moschata), zucchini squash (Cucurbita pepo), bottle gourd (Lagenaria siceraria), ash gourd (Benincasa hispida), ridge gourd (Luffa acutangula) sponge gourd (Luffa cylindrica), kumatikai (Citrullus colocynthis) and African horned cucumber (Cucumis metuliferus) were collected from different parts of Tamil Nadu and India were used for grafting study.

\section{Grafting}

Grafting was performed under shade net house allowing only 25 per cent sunlight. In this structure relatively low temperature with high humidity was maintained in comparison with the outside environment. The relative humidity inside the greenhouse ranged between 60 and 70 per cent and temperature between 25 and $27^{\circ} \mathrm{C}$.

The grafting method adopted in this study was side grafting. Immediately after grafting, the plants were transferred to a healing chamber and kept for seven days at $\mathrm{RH}>95 \%, 29^{\circ} \mathrm{C}$ and darkness (shaded conditions). Relative humidity was reduced gradually for acclimatization. Seven days after grafting, the plants were transferred to greenhouse and transplanted in the main field after acclimatization. The observations viz., Number of days taken to attain graftable size of rootstocks, Days taken for graft union and graft success percentage at 15, 30 and 45 days after grafting (DAG) was recorded.

\section{Microtome study}

In order to study the ultra structural changes and compatibility of grafted bitter gourd plants, microtome study was taken up and anatomical observation were carried out @ $7,15,21$ and 30 days after grafting under microscope following the method suggested by Johansen (1940).

\section{Killing and fixing}

The specimens (graft union portion) were killed and fixed in FAA solution for minimum 24 hours (FAA: 10:50:5:35 proportion of formalin, alcohol, acetic acid and water).

\section{Dehydration}

After killing and fixing the materials in FAA solution, the samples were washed with 50 per cent ethanol and then transferred to tertiary butyl alcohol series of $60,70,80,90$ and 100 per cent for one hour followed by 12 hours in 100 per cent tertiary butyl alcohol (TBA).

\section{Infiltration with wax}

After the process of dehydration, they were transferred to TBA + wax series of $2 / 3+1 / 3$, $1 / 2+1 / 2,1 / 2+1 / 3$ and absolute wax two times for 30 to 45 minutes in each series.

\section{Embedding}

Next to infiltration process, the material was embedded in wax with melting point of 52 $54^{\circ} \mathrm{C}$. For this molten $\max$ was poured into paper boat, with inner side smeared with glycerin. The infiltrated pieces were placed in molten wax in the proper orientation. The blocks were cut in such a way that each block contained one solution.

\section{Sectioning}

The paraffin embedded specimens were sectioned with the help of rotary microtome. The thickness of sections was 10-12 $\mu \mathrm{m}$. 


\section{Dewaxing and staining}

The dewaxing was done using xylene alcohol mixture. The slides containing sections were kept for half an hour in pure xylene ( 2 times), ethanol + xylene (1:1), 90, 70, 50 per cent ethanol. The slides were kept in saffranine solution for 12 hours and subsequently transferred to 50, 70, 90 per cent ethanol for 10 minutes in each series. Then the slides were dipped in alcohol: ammonia and alcohol: picric acid mixture. Then the slides were transferred to 70 per cent alcohol for 2-3 minutes. Fast green solution was added over the sections and stain was drained with clove oil and washed with distilled water. Slides were transferred to alcohol: xylene mixture (two times for ten minutes).

\section{Mounting}

Glycerin mounted temporary preparations were made for macerated / cleared materials. Powdered materials of different parts were cleared with $\mathrm{NaOH}$ and mounted in glycerin medium after staining. Different cell components were studied.

\section{Photomicroscopy}

Observations on the cellular changes were made using microscope (Laborluxs, Leitz, Austria) under bright field cold illumination. Sections were micrographed in Kodak photo film using Sony camera. Descriptive terms of the anatomical features are described as given in the standard anatomy books (Esau, 1964).

\section{Statistical analysis}

Treatments were defined by completely randomized block design with three replicates per treatment. The data were statistically analyzed using the IRRISTAT version 92 developed by the International Rice Research Institute Biometrics Unit, the Philippines
(Gomez and Gomez, 1984). Data were subjected to analysis of variance (ANOVA) at two significant levels $(\mathrm{P}<0.05$ and $\mathrm{P}<0.01)$ and means were compared by Duncan's Multiple Range Test (DMRT).

\section{Results and Discussion}

Earliness in terms of number of days taken for germination was presented in Table 1. Among the ten rootstocks, significantly less number of days (3.60) were required for germination of zucchini squash seeds compared to other rootstocks. However results were on par with sponge gourd (3.90 days) rootstocks and maximum number of days (25.30) for germination was recorded by kumatikai (Citrulus colocynthis) followed by African horned cucumber (Cucumis metuliferus) (14.80) and the growth was also too slow. In case of scions, Palee $F_{1}$ required significantly less number (4.40) of days for germination followed by $\mathrm{CO} 1$ scion were required 7.8 days for germination. Based on the observation CO 1 seeds were sown one week prior to sowing of rootstock seeds. Hard/ thick seed coat and high oil content are the major problems associated with delayed seed germination.

The number of days taken for graft union fusion is an important trait, which indirectly increases the yield of crop plants. As soon as the union of graft was completed, it can be transplanted and allowed to grow for its performance (Dhivya, 2014). The data pertaining to number of days taken to attain graftable size varied significantly among the rootstocks and scions (Table 1). Among the rootstocks, zucchini squash (Cucurbita pepo) and fig leaf gourd (Cucurbita ficifolia) recorded significantly less (14.80 and 20.80) number days whereas kumatikai (Citrulus colocynthis) followed by African horned cucumber (Cucumis metuliferus) recorded maximum number of days (60.00 and 45.10 
respectively) to attain graftable size. The stem thickness of these rootstocks did not match with the thickness of bitter gourd scion. Hence these rootstocks were not included for grafting experiment. Seeds of pumpkin germinate later than sponge gourd but these seedlings are ready to attain graftable size earlier (22.7 days) than sponge gourd. Similar reports were obtained by Reyes (1990).

The graft was considered functional in 4 to 8 days after grafting (DAG) as vascular strands are formed and fully functional after 15 days when several connections will be completed. Among the eight rootstocks used for grafting, pumpkin (C. moschata) took the least average number of days (5.03 and 6.06) for graft union fusion with Palee $\mathrm{F}_{1}$ and $\mathrm{CO} 1$ while fig leaf gourd ( $C$. ficifolia) recorded the highest average number of days (9.06 and 8.83 ) for graft union fusion with Palee $\mathrm{F}_{1}$ and $\mathrm{CO} 1$ through side grafting. Moreover, pumpkin recorded the highest success per cent of 89.05 at $15^{\text {th }}$ DAG, 78.90 at $30^{\text {th }}$ DAG and 71.70 at $45^{\text {th }}$ DAG followed by sponge gourd which recorded 85.35 at $15^{\text {th }}$ DAG, 74.35 at $30^{\text {th }}$ DAG and 68.26 at $45^{\text {th }}$ DAG. The lowest graft success $(50.95,25.45$ and 12.12) was observed in mithipakal rootstock followed by bitter gourd scion with fig leaf gourd (45.00, 33.45 and 15.04$)$ at $15^{\text {th }}, 30^{\text {th }}$ and $45^{\text {th }}$ days after grafting (Fig.1). Petran and Hoover (2014) reported that $S$. torvum rootstock had the highest average days to fusion (12.3 days) with 'Celebrity'; scion compared to any other graft combination and had the lowest survival percentage $(50 \%)$. Similar trends of results were obtained by Punithaveni (2015) who reported that 'Green long' cucumber grafted onto bottle gourd rootstock took least average number of days for graft union fusion and recorded highest success percentage $(85 \%)$ with hole insertion grafting and Dhivya (2014) reported that grafting TNAU Tomato hybrid CO-3 on $S$. torvum registered the least number of days for graft union fusion (9.10) and highest success percentage (90.67) with cleft grafting.

In case of ash gourd (Benincasa hispida) and zucchini squash (Cucurbita pepo), quick wilting occurs immediately after grafting. This is a characteristic of graft incompatibility, which contributes to poor vascular connection with poor connecting sieve tubes, cambium and xylem in the heterograft Cucumis/Cucurbita (Salehi et al., 2008). Sudden wilting is also due to physiological incompatibility as a result of lack of cellular recognition, wounding responses, presences of growth regulators or incompatible toxins. In the incompatible combinations, the leaves turned yellow and plants withered (Davis et al., 2008). This study is in agreement with other studies performed with melon scions with $L$. siceraria, $C$. ficifolia and C. moschata rootstocks (Morra, 1997; Miguel, 2004).

Transverse sections were taken from the graft union region at $7^{\text {th }}, 15^{\text {th }} 21^{\text {st }}$ and $30^{\text {th }}$ days after grafting in the two graft combinations viz., Palee $\mathrm{F}_{1}$ scion grafted with pumpkin (Cucurbita moschata) rootstock and fig leaf gourd (Cucurbita ficifolia) rootstock. Grafting causes a wound response at the graft interface that result in the formation of a necrotic layer. A dark strands of necrotic/ proliferation layers were seen in outer sides and interfaces of Palee $\mathrm{F}_{1}$ grafted on to pumpkin (Cucurbita moschata) rootstock at $7^{\text {th }}$ day after grafting (Fig.2A). Lilieth et al., (2012) reported that the high survival rates observed Scotch Bonnet/Black Beauty heterograft combinations indicated the establishment of wound repair xylem across the graft union, thereby allowing the movement of water and mineral nutrients between the rootstock and the scion. Evidence of such wound response development was also reported by Sherly (2011) in brinjal and Dhivya (2014) in tomato. 
Table.1 Performance of cucurbitaceous rootstocks and bitter gourd scions on number of days taken for germination and number of days taken to attain graftable size

\begin{tabular}{|l|c|c|}
\hline \multicolumn{1}{|c|}{ Rootstocks } & $\begin{array}{c}\text { Number of days } \\
\text { taken for } \\
\text { germination }\end{array}$ & $\begin{array}{c}\text { Number of days } \\
\text { taken to attain } \\
\text { graftable size }\end{array}$ \\
\hline Mithipakal (Momordica charantia var. muricata) & 8.70 & 27.30 \\
\hline Fig leaf gourd (Cucurbita ficifolia) & 4.80 & 20.80 \\
\hline Pumpkin (Cucurbita moschata) & 4.60 & 22.70 \\
\hline Zucchini squash(Cucurbita pepo) & 3.60 & 14.80 \\
\hline Sponge gourd (Luffa cylindrica) & 3.90 & 23.10 \\
\hline Ridge gourd (Luffa acutangula) & 4.30 & 25.20 \\
\hline Bottle gourd (Lagenaria siceraria) & 6.10 & 24.80 \\
\hline Ash gourd (Benincasa hispida) & 10.80 & 36.50 \\
\hline Kumatikai (Citrullus colocynthis) & 25.30 & 60.00 \\
\hline $\begin{array}{l}\text { African horned cucumber } \\
\text { (Cucumis metuliferus) }\end{array}$ & 14.80 & 45.00 \\
\hline Scions & & \\
\hline Palee F $_{1}$ & 4.40 & 21.10 \\
\hline CO 1 & 7.80 & 26.40 \\
\hline
\end{tabular}

Fig.1 Effect of rootstocks on grafting success in bitter gourd scions at 15,30 and 45 days after grafting (DAG)

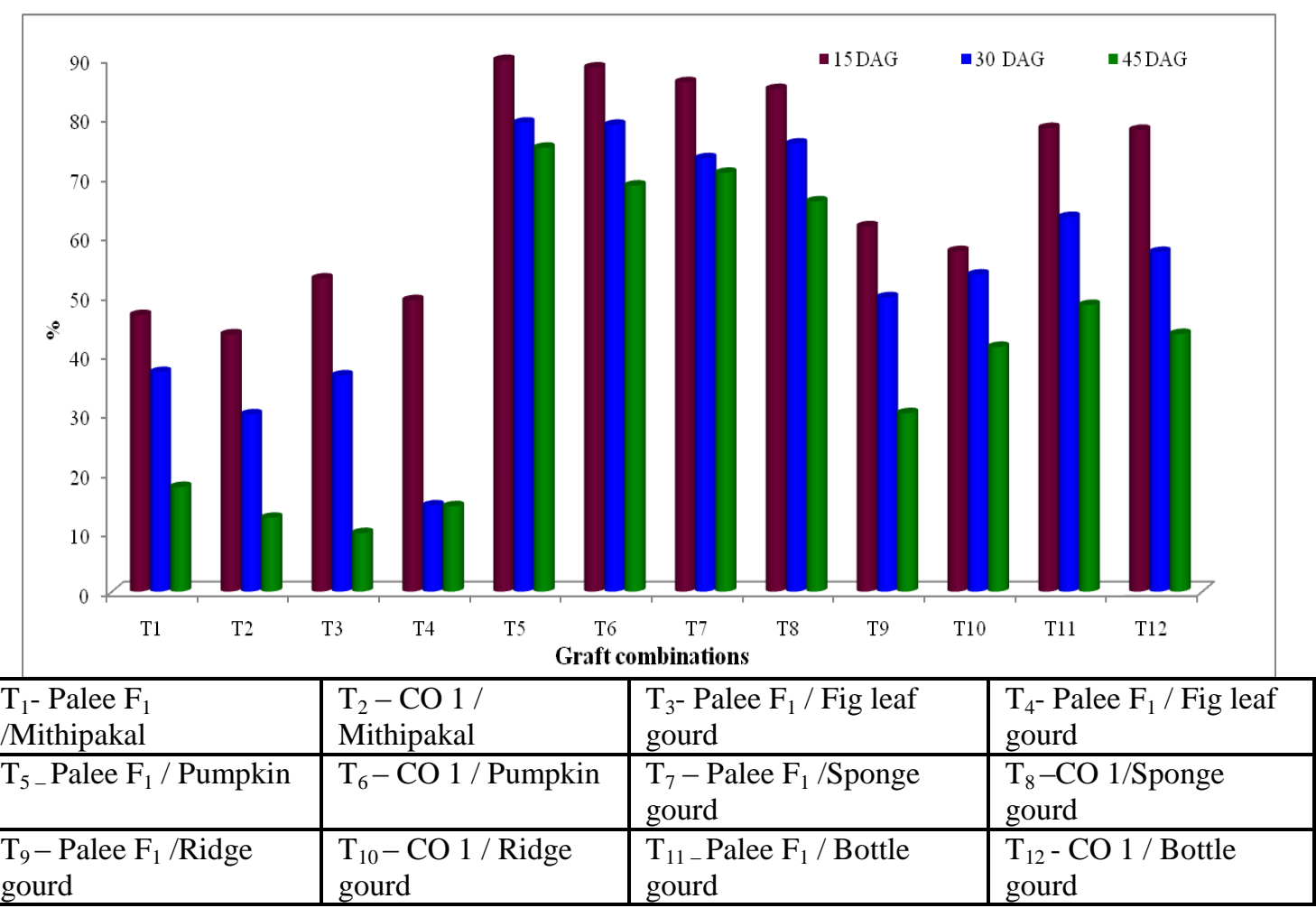

Number of individuals per sample is 50; Number of individuals observed per sample is 50; number of replicates -3 
Fig.2 Anatomical view of compatible graft combination and incompatible graft combination
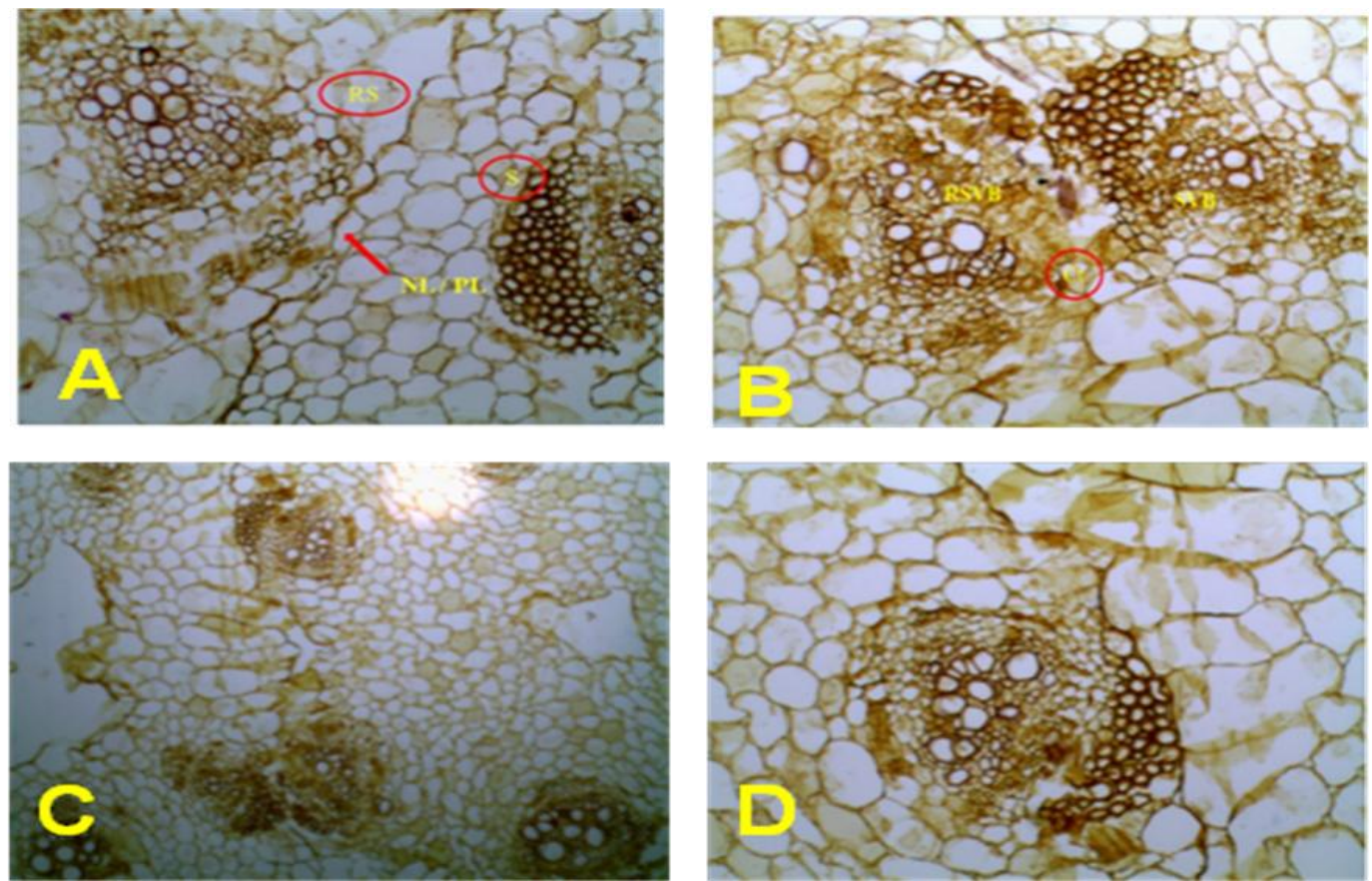

A. Anatomical view of Palee $\mathrm{F}_{1}$ scion + Pumpkin rootstock at 7DAG. RS: Rootstock; S: Scion; NL/PL: Necrotic layer or Proliferation layer

B. 15 days old Palee $F_{1}$ scion+ pumpkin rootstock graft combination. RSVB: Rootstock vascular bundle; SVB:

Scion vascular bundle

C. Vascular union formation at $21 \mathrm{DAG}$ in Palee $\mathrm{F}_{1}$ scion + Pumpkin rootstock

D. Complete union of vascular bundles of rootstock and scion at $30 \mathrm{DAG}$

Fig.2 F \& G Cross section of incompatible graft union of Palee $\mathrm{F}_{1}$ scion + Fig leaf gourd (C. ficifolia) rootstock
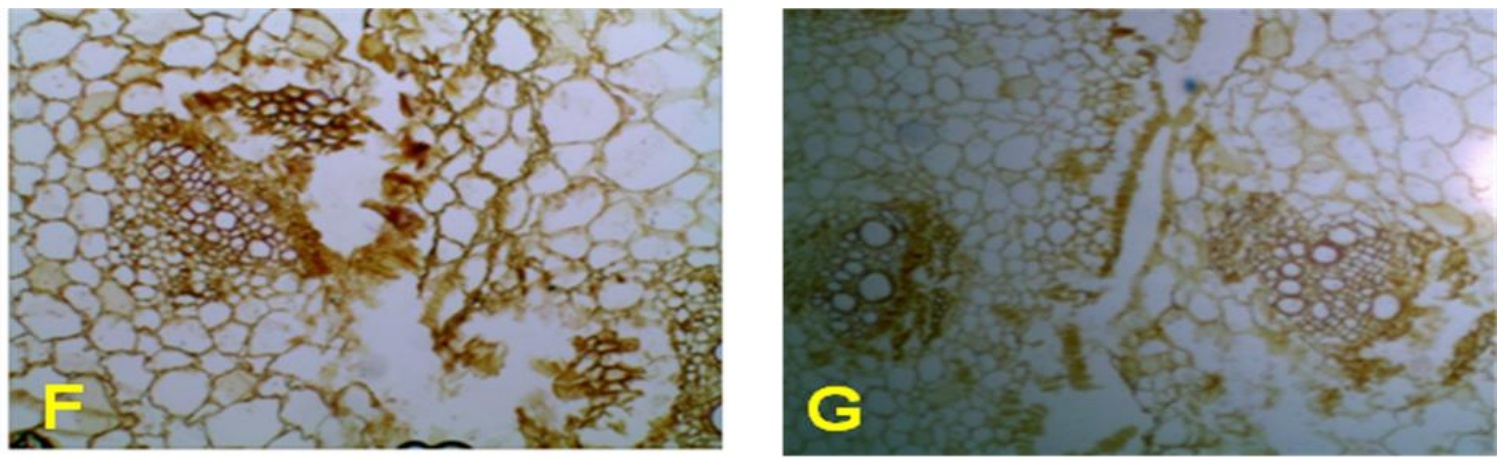

Disintegration of wounded surface followed by vascular bundles

In case of Palee $\mathrm{F}_{1}$ grafted onto fig leaf gourd (Cucurbita ficifolia) rootstock, the wounded surface of stock and scion at the graft joint get disintegrated which leads to severe misalignment may result in complete failure of graft union (Fig.2F \& G). These cells never conduct water and food material that automatically leads to incompatibility. This phenomenon has been attributed to nonvascular connections between the rootstock 
and scion. The ability to survive at 7 days and 30 days after grafting were significantly different in this graft combination indicating delayed incompatibility. Histological examination of the same provided clear evidence of discontinuous xylem elements in the graft union as well as large areas of unbroken necrotic lines along the wounded edges of the rootstock and the scion. This result is consistent with the findings of Kawaguchi et al., (2008) and Lilieth et al. (2012) in Scotch Bonnet/Black Beauty heterograft combinations

At $15^{\text {th }}$ day after grafting, the bitter gourd scions grafted onto pumpkin (Cucurbita moschata) rootstock attained the mechanical strength as illustrated by their ability to remain intact upon removal of grafting clips (Fig.2B). During this stage a limited callus formation was seen in the aforementioned compatible combination. As these callus tissues multiply, they begin absorbing the necrotic layer, thus forming a callus bridge between the graft partners. Callus started to spread into gaps between graft partners by fusing into the proliferation layer. These callus bridges allow the flow of xylem exudates between rootstock and scion tissues thereby increasing survival in graft combinations. Richardson et al., (1996) used this method to test the mechanical strength of in vitro micro-grafted apples, and obtained similar results in a similar time span. Lilieth et al., (2012) also obtained similar findings when grafting Scotch Bonnet auto grafts and hetero-grafts on Akash, Black Beauty and bitter gumma rootstocks by 21 days post grafting. Satisfactory callus production and vascular bundle differentiation was noticed at $21^{\text {st }}$ day after grafting (Fig.2C). At this stage, complete differentiation of vascular bundles across the callus bridge could be seen the compatible combination. Callus proliferation was observed between interspaces of stock and scion. This adhesion of callus cells allows for the interconnection of opposing plasmodesmata, which further strengthens the graft union. Histological observation at $30^{\text {th }}$ day after grafting showed the complete fusion of rootstock and scion. The wound healing was almost complete. The cambial cells were connected as a continuous ring and cambial continuity were occurred successfully between the rootstock and scion at the graft joint (Fig.2D). This result is consistent with the findings of Lilieth et al., (2012) who reported a high degree of graft compatibility was noticed between Scotch Bonnet scions grafted onto Black Beauty rootstocks. Evidence for high percentage of graft success and establishment of vascular tissue connectivity was observed in the histological study. Dhivya (2014) and Punithaveni (2015) obtained the same result in tomato and cucumber respectively.

Evidence of high success percentage, secondary growth of the scion, histological examination of graft union at different day interval and excellent growth the scion at 30 days after grafting may responsible for compatibility between the bitter gourd scions and pumpkin rootstock. Evidence of this low success per cent, presence of unbroken or slightly fragmented necrotic layer and stunted growth of Palee $F_{1}$ scion grafted onto fig leaf gourd (Cucurbita ficifolia) rootstock leads to incompatibility. Finally, the results of the study indicated that, based on success per cent and microtome study, pumpkin could be a compatible rootstock for grafting with bitter gourd scions.

\section{References}

Alai, S.M.R. 2014. Evaluating the graft success between (S.macrocarpon) and two S. lycopersicon (tomato) varieties (Petomech and Roma) using the splice graft method, B.Sc. Thesis, University of Ghanarieties.

Anon. 2015-16.www.indiastat.com

Davis, A.R., Veazie, P.P., Sakata, Y., 
Galarza, S.L., Maroto, J.V., Lee, S.G., Huh, Y.C., Sun, Z., Miguel, A., King, S.R., Cohen, R. and Lee, J.M. 2008, Cucurbit Grafting. Crit. Rev. Pl. Sci., 27(1): 50 -74.

Dhivya, R. 2014. Screening studies of wild rootstocks for biotic stresses and its performance on grafting in tomato. Ph.D (Hort.) Thesis, Tamil Nadu Agricultural University, Coimbatore.

Easu, K.1964. Plant anatomy. John Wiley and Sons, New York, pp: 767.

Elazar, F. and Zoran, I. 2014. Grafted vegetables - the influence of rootstock and scion on post harvest quality. Folia Hort., 26(2): 79-90.

Gautam, S.K and Poddar, A.N. 2014. Study on protein and sugar content in Meloidogyne incognita infested roots of bitter gourd. Int. J. Curr. Microbiol. App. Sci., 3(5): 470-478.

Gomez, K.A. and Gomez, A.A. 1984. Statistical Procedure for Agricultural Research, New York: Wiley.

Hartmann, H.T., Kester, D.E., Davies, F.T and Geneve, R.L. 2011. Plant Propagation: Principles and Practices. Eight edition. New York: Prentice Hall

Johansen, D.P. 1940. Plant Micro technique, Mc Graw Hill Book Co. Inc., New York.

Kaur, S. and Pathak, M. 2011. Sources of resistance in Varh Karela (Momordica balsamina L.) to root knot nematode. Pl. Dis. Res., 26(2): 174.

Kawaguchi, M., Taji, A., Backhouse, D. 2008. Anatomy and physiology of graft incompatibility in Solanaceous crops, $J$. Hort. Sci. Biotech., 83: 581-588.

Kleinhenz, D. M., Monicah, W. J. M.E and Sally A. M. 2013. Tomato grafting guide: a quick guide to splice and Cleft Graft Method. Retrieved from http://hortcrsp.ucdavis.edu/main/Deliver ables/Kleinhenz/tomato grafting guide.pdf on 20/10/201
Kohatsu, D.S., Zucareli, V., Brambilla, W.P., Elizabeth, O., Silva, T.R.B and Rodrigues, J.D. 2013. Peroxidase and polyphenol oxidase activity on the yield of grafted and ungrafted cucumber plants. African J. Agric. Res., 8(3): 279283.

Lilieth, I., Richard, B., Gregor, B., Wendy, A. I., Clare, B.C. and Isaac, B. 2012.Graft Compatibility of Scotch Bonnet (Capsicum chinense Jacq) with Selected Salt-Tolerant Solanaceous. J. of Agric. Sci. Tech., B 2: 81-92

Miguel, A. 2004. Use of grafted cucurbits in the Mediterranean Region as an alternative to Methyl Bromide. Proc. Fifth International Conference on Alternatives to Methyl Bromide, Lisbon: 151-156.

Morra, L. 1997. Linnesto erbaceo coltura per coltura. Colture Protette, 5: 17-22.

Nkansah, G.O., Ahwereng, A.K., Amoatey, C. and Ayarna, A.W. 2013. Grafting unto African eggplant enhances growth, yield and fruit quality of tomatoes in tropical forest ecozones. J. Appl. Hort., 15(1): 16-20.

Petran, A. and Hoover, E. 2014. Solanum torvum as a Compatible Rootstock in Interspecific Tomato Grafting. J. Hort., 1: $\quad 103 . \quad$ DOI: $10.4172 / 2376-$ 0354.1000103.

Punithaveni, V. 2015. Standardization of grafting techniques in cucumber for resistance to root knot nematode and Fusarium wilt. Ph.D (Hort.) Thesis, Tamil Nadu Agricultural University, Coimbatore.

Reyes, M.E.C. 1990. A preliminary study of graft compatibility of bitter gourd scion on sponge gourd and bottle gourd rootstocks, ARC Gourd Training Report, pp 1-5

Richardson, F.V.M., Saoir, S.M., Harvey, B.M.R. 1996. A study of the graft union in in vitro micrografted apple. Plant 
Growth Regul., 20: 17-23.

Salehi, R., Kashi, A.K. and Javanpoor, R. 2008. Effect of grafting on survival of cucumber, watermelon and melon plants grafted onto cucurbita spp. rootstocks by hole insertion grafting. Acta Hort., 771: 141-144.

Shehata, S.A.M., Salama, G.M and Eid, S.M. 2000. Anatomical studies on cucumber grafting. Annuals of Agri. Sci., 38(4):2413-2423

Sherly, J. 2010. Studies on grafting of brinjal accessions (Solanum melongena L.) with wild solanum rootstocks. Ph.D (Hort.) Thesis, Tamil Nadu Agricultural University, Coimbatore.

Singh, S.K., Conde, B. and Hodda, M. 2012. Root-Knot Nematode (Meloidogyne incognita) on Bitter Melon (Momordica charantia) near Darwin, Australia. Australas. Pl. Dis. Notes, 7: 75-78.

Tamilselvi, N.A. 2014. Grafting studies in bitter gourd. Ph.D (Hort.) Thesis, Tamil Nadu Agricultural University, Coimbatore.

\section{How to cite this article:}

Tamilselvi, N.A. and Pugalendhi, L. 2017. Graft Compatibility and Anatomical Studies of Bitter Gourd (Momordica charantia L.) Scions with Cucurbitaceous Rootstocks. Int.J.Curr.Microbiol.App.Sci. 6(2): 1801-1810. doi: http://dx.doi.org/10.20546/ijcmas.2017.602.202 